\title{
Ethnobotanical Survey of Medicinal Plants in Nagari Tuo Pariangan, West Sumatera
}

\author{
Wika Mardiyah ${ }^{1 *} \mathrm{~N} \mathrm{Nisyawati}^{1} \mathrm{M} \mathrm{Silalahi}^{2}$
}

\author{
${ }^{1}$ Biology Department, Faculty of Mathematics and Sciences, Universitas Indonesia Jakarta, Indonesia \\ ${ }^{2}$ Biology Education Department, Faculty of Teacher Training and Education, Universitas Kristen, Indonesia, Jakarta, \\ Indonesia \\ *Corresponding author. Email: wika1210422001@gmail.com
}

\begin{abstract}
An ethnobotanical survey of medicinal plants was carried out among Minangkabau tribe in NagariTuoPariangan, West Sumatera. The survey was carried out to gather information on the use of medicinal plants in order to learn about traditional knowledge of NagariTuoPariangan community. Semistructured interview was used to conduct this survey. Fifty three respondents consisting of 7 key informants and 47 general respondents were interviewed. A total of 47 species of plants distributed in 46 genera belonging to 28 families were identified as commonly used medicinal plants by NagariTuoPariangan community for digestive disease. In this study, documenting the medicinal plants and associated traditional knowledge can be used to conserve and sustain the utilization of medicinal plants in NagariTuoPariangan community. Extensive research on such medicinal plants are important to validate scientifically their ethnomedical knowledge.

Keywords: digestion, ethnobotany, medicinal plants, Pariangan.
\end{abstract}

\section{INTRODUCTION}

The utilization of plants as medicine has started since 4000 - 5000 BC by the people of China[1]. Until today, researches which study the knowledge of medicinal plants within the scope of ethnobotany among the traditional society of Indonesia are still focused on Java Island and only a few on Sumatera Island. A village in Sumatera Island that is occupied by traditional society is NagariTuoPariangan. NagariTuoPariangan is pretty close to the city center, which enables easy access for the people to obtain synthetic drug. Easy access makes the people tend to use synthetic drugs because it is more practical. The tendency to use synthetic drugs may cause degradation towards the traditional community's knowledge[2].

Digestive disease is one of the most common diseases occurred to the people of NagariTuoPariangan, according to the conducted initial survey. Digestive disease includes stomachache, gastroesophageal reflux disease, constipation, dysentery, diarrhea, and meteorismus. This symptom shows due to foods that are hard to digest, overeating or irregular eating, unbalanced diet, spicy food, and drinking water contamination[3,4]. The research to record the knowledge of NagariTuoPariangan community in the utilization of medicinal plants to cure digestive disease has never been conducted before. The nonexistence of documentation may result in the degradation of the Nagari Tuo Pariangan community's knowledge on ethnobotany of medicinal plants from generation to generation.
Based on this problem, a survey on the ethnobotany of medicinal plants in NagariTuoPariangan was necessary. This survey aimed to record and to study the knowledge of NagariTuoPariangan traditional community about medicinal plant. The studied medicinal plants were plants used to cure digestive disease.

\section{MATERIAL AND METHODS}

\section{Time and Location}

The research was conducted on May - June 2019. The data were collected at NagariTuoPariangan, West Sumatera. The tribe that became the research target was Minangkabau tribe at four jorong (Pariangan, Sikaladi, Padangpanjang, andGuguak). Plant species identification was conducted atAndalasHerbarium, Biology Department, Faculty of Mathematics and Sciences,Andalas University.

\subsection{Respondents}

The respondents within this research were 54 people, consisted of key informants (7 people) and common respondents (47 people). Key informants consisted of WaliNagari (1 people), leader of jorong (4 people), leader of custom (1 people), and bundokanduang (1 people). Key informants was selected based on the knowledge and experience in utilizing local plants. The common respondents were selected using purposive sampling, under the condition that they had the knowledge on medicinal plant and are married. The common respondents 
were also selected using snowball sampling method based on the information from the key informants.

\subsection{Data Analysis}

The data analysis was performed descriptively based on the knowledge of Nagari Tuo Pariangan traditional community in the utilization of medicinal plants for digestive disease.

\section{RESULT AND DISCUSSION}

Based on the research result, it was found that Nagari Tuo Pariangancommunity utilized 47 species of medicinal plants to cure digestive disease, belonging to 46 genus and 28 family (Table 1). Digestive disease consisted of toothache, mouth ulcer (sariawan), gastritis (tukak lambung), stomachache, dysentery, diarrhea, nausea (mual), meteorismus, swollen stomach, gastroesophageal reflux, stomach burn, stomach cramps, and intestine cancer. The parts of the plant that were used as the medicine were the leaf, bud, pistil, ripe fruit, young fruit, fruit's peel, pulp, blossom, stem, sap, stem bud, water in trunk cavity, root, and bulb.

Table 1. Medicinal plants that used to cure digestive disease by Nagari Tuo Pariangan community, West Sumatra

\begin{tabular}{|c|c|c|c|c|c|}
\hline Family & Scientific Name & Habitus & Local Name & $\begin{array}{l}\text { Parts of } \\
\text { the } \\
\text { Plant }\end{array}$ & Benefits \\
\hline \multirow[t]{2}{*}{ Rubiaceae } & Uncariagambir(Hunter) Roxb. & Climber & Gambia & $\begin{array}{l}\text { Leaf, } \\
\text { stem }\end{array}$ & Gastritis \\
\hline & PaederiafoetidaL. & Climber & Sentri & Leaf & $\begin{array}{c}\text { Stomachache, } \\
\text { dysentery }\end{array}$ \\
\hline Sapotaceae & Manilkarazapota(L.) P.Royen & Tree & Saus & $\begin{array}{l}\text { Ripe } \\
\text { fruit, } \\
\text { young } \\
\text { fruit, } \\
\text { root, } \\
\text { sap, } \\
\text { pistil }\end{array}$ & $\begin{array}{c}\text { Stomachache, } \\
\text { diarrhea }\end{array}$ \\
\hline \multirow[t]{3}{*}{ Rutaceae } & $\begin{array}{l}\text { Citrus aurantifolia(Christm.) } \\
\text { Swingle }\end{array}$ & Tree & Asamkapeh & $\begin{array}{l}\text { Ripe } \\
\text { fruit }\end{array}$ & $\begin{array}{l}\text { Stomachache, } \\
\text { gastritis }\end{array}$ \\
\hline & ClausenaexcavataBurm.f. & Tree & Sicerek & Leaf & Stomachache \\
\hline & Citrus hystrix DC. & Tree & Asamsundai & $\begin{array}{l}\text { Ripe } \\
\text { fruit }\end{array}$ & $\begin{array}{l}\text { Stomachache, } \\
\text { nausea }\end{array}$ \\
\hline Amaryllidaceae & Allium cepa $\mathrm{L}$. & Herbs & Bawangmerah & Bulb & $\begin{array}{l}\text { Meteorismus, } \\
\text { stomachache }\end{array}$ \\
\hline \multirow[t]{3}{*}{ Zingiberaceae } & Curcuma longa $\mathrm{L}$. & Herbs & Kunyik & Bulb & $\begin{array}{c}\text { Gastritis, } \\
\text { meteorismus, } \\
\text { swollen stomach, } \\
\text { gastroesophageal } \\
\text { reflux, } \\
\text { stomachache, } \\
\text { intestine cancer, } \\
\text { stomach burn, } \\
\text { toothache }\end{array}$ \\
\hline & Zingiberofficinale Roscoe & Herbs & Sipadeh & Bulb & $\begin{array}{c}\text { Stomachache, } \\
\text { stomach cramps, } \\
\text { gastritis, stomach } \\
\text { burn }\end{array}$ \\
\hline & Etlingeraelatior(Jack) R.M.Sm. & Herbs & Sijengkeng & Root & Gastritis \\
\hline
\end{tabular}




\begin{tabular}{|c|c|c|c|c|c|}
\hline Solanaceae & NicotianatabacumL. & Herbs & Timakau & Leaf & Meteorismus \\
\hline & Capsicum annum $\mathrm{L}$. & Herbs & Ladomerah & Leaf & $\begin{array}{l}\text { Stomachache, } \\
\text { mouth ulcer }\end{array}$ \\
\hline & SolanumlycopersicumL. & Herbs & Tomat & $\begin{array}{l}\text { Ripe } \\
\text { fruit }\end{array}$ & Intestine cancer \\
\hline & Physalis minima L. & Herbs & Latuik-latuik & All part & Gastritis \\
\hline \multirow[t]{6}{*}{ Poaceae } & Oryza sativa $\mathrm{L}$. & Grass & Padi & $\begin{array}{l}\text { Ripe } \\
\text { fruit }\end{array}$ & Stomachache \\
\hline & Gigantochloaatter(Hassk.) Kurz & Bamboo & Buluah & $\begin{array}{c}\text { Water in } \\
\text { trunk } \\
\text { cavity }\end{array}$ & Stomach burn \\
\hline & $\begin{array}{l}\text { Dendrocalamusasper(Schult.) } \\
\text { Backer }\end{array}$ & Bamboo & Batuang & $\begin{array}{l}\text { Water in } \\
\text { trunk } \\
\text { cavity }\end{array}$ & Stomach burn \\
\hline & LeersiahexandraSw. & Grass & Banto & Leaf & Stomach burn \\
\hline & Imperata cylindrical(L.) Raeusch & Grass & Ilalang & Leaf & Stomach burn \\
\hline & Cymbopogon citrates(DC.) Stapf & Herbs & Sarai & Stem & Toothache \\
\hline \multirow[t]{3}{*}{ Compositae } & Artemisia vulgaris L. & Herbs & Capo & Leaf & $\begin{array}{l}\text { Gastroesophageal } \\
\text { reflux }\end{array}$ \\
\hline & Ageratum conyzoides(L.) L. & Herbs & Busuakputiah & Leaf & $\begin{array}{l}\text { Gastritis, swollen } \\
\text { stomach }\end{array}$ \\
\hline & VernoniaamygdalinaDelile & Shrub & Daun Afrika & Leaf & Toothache \\
\hline Leguminosae & Vignasp. & Herbs & Kacangtujuahhalai & Leaf & $\begin{array}{l}\text { Stomachache, } \\
\text { stomach burn }\end{array}$ \\
\hline \multirow[t]{2}{*}{ Musaceae } & Musa $\times$ sapientum L. & Herbs & Pisangrajo & $\begin{array}{c}\text { Stem } \\
\text { bud }\end{array}$ & Stomachache \\
\hline & $\begin{array}{l}\text { Musa balbisianavar. } \\
\text { brachycarpa(Backer) Häkkinen }\end{array}$ & Herbs & Pisangbatu & Blossom & Stomach cramps \\
\hline Moraceae & ArtocarpusheterophyllusLam. & Tree & Cubadak & Leaf & Stomachache \\
\hline Cucurbitaceae & Benincasahispida(Thunb.) Cogn. & Climber & Kunduabatang & Ripe fruit & $\begin{array}{c}\text { Stomach burn, } \\
\text { stomachache, mouth } \\
\text { ulcer }\end{array}$ \\
\hline Salicaceae & $\begin{array}{l}\text { Homalanthuspopulneus(Geiseler) } \\
\text { Pax }\end{array}$ & Tree & Budi & Leaf & Stomachache \\
\hline \multirow[t]{2}{*}{ Euphorbiaceae } & ManihotesculentaCrantz & Shrub & Pucuakubi & $\begin{array}{l}\text { Ripe fruit, } \\
\text { bulb }\end{array}$ & $\begin{array}{c}\text { Gastritis, } \\
\text { gastroesophageal } \\
\text { reflux }\end{array}$ \\
\hline & RicinuscommunisL. & Shrub & Jirak & Leaf & Stomachache \\
\hline Myrtaceae & PsidiumguajavaL. & Tree & Paraweh & $\begin{array}{c}\text { Pistil, ripe } \\
\text { fruit, fruit's } \\
\text { peel, root }\end{array}$ & Diarrhea \\
\hline Lauraceae & PerseaamericanaMill. & Tree & Pokat & Bud & Dysentery \\
\hline \multirow[t]{2}{*}{ Lamiaceae } & Orthosiphonaristatus(Blume) Miq. & Herbs & Sunguikkuciang & Leaf & $\begin{array}{l}\text { Stomachache, } \\
\text { stomach burn }\end{array}$ \\
\hline & $\begin{array}{l}\text { Plectranthusscutellarioides(L.) } \\
\text { R.Br. }\end{array}$ & Herbs & Piladangungu & Leaf & Nausea \\
\hline Loranthaceae & Taxillusferrugineus(Jack) Bân & Parasite & Binalu kopi & Leaf & Gastritis \\
\hline Talinaceae & Talinumpaniculatum(Jacq.) Gaertn. & Herbs & Ginseng & All parts & Dysentery \\
\hline Acanthaceae & Graptophyllumpictum(L.) Griff. & Shrub & Pudianghitam & Leaf & Gastritis \\
\hline Sapindaceae & NepheliumlappaceumL. & Tree & Rambutan & Bud & Stomach burn \\
\hline
\end{tabular}




\begin{tabular}{|c|l|c|c|c|c|}
\hline Urticaceae & $\begin{array}{l}\text { Poikilospermumsuaveolens(Blume) } \\
\text { Merr. }\end{array}$ & $\begin{array}{c}\text { Climber } \\
\text { shrub }\end{array}$ & Lundang & Root & Stomach burn \\
\hline Malvaceae & Hibiscus rosa-sinensisL. & Shrub & Bungorayoputiah & Leaf & Stomach burn \\
\hline & Abelmoschusmanihot(L.) Medik. & Shrub & Parasetamol & Leaf & Mouth ulcer \\
\hline Arecaceae & CocosnuciferaL. & Tree & Karambia & $\begin{array}{c}\text { Ripe } \\
\text { fruit }\end{array}$ & Stomach burn \\
\hline Annonaceae & AnnonamuricataL. & Tree & $\begin{array}{c}\text { Durian lauik/durian } \\
\text { balando }\end{array}$ & Leaf & $\begin{array}{c}\text { Intestine cancer, } \\
\text { toothache }\end{array}$ \\
\hline Boraginaceae & SymphytumofficinaleL. & Herbs & Daun ginjal & Leaf & Toothache \\
\hline Caricaceae & Carica papayaL. & Tree & Kalikih & Sap & Toothache \\
\hline Piperaceae & Piper ningrumL. & $\begin{array}{c}\text { Climber } \\
\text { shrub }\end{array}$ & Merica & $\begin{array}{c}\text { Ripe } \\
\text { fruit }\end{array}$ & Toothache \\
\hline
\end{tabular}

mostly use medicinal plants to cure diseases before using synthetic drugs, while the people of 40-50 years old

Modern medical facilities are available in Nagari Tuo Pariangan, but the people still use medicinal plants to cure some diseases. The people of 60-70 years old mostly use medicinal plants to cure diseases before using synthetic drugs. The people of 40-50 years old mostly use synthetic drug before using medicinal plants. The medicinal plants used were fewer compared to other places in Sumatera Island, like in Bengkulu. The people of Bengkulu use 68 species of medicinal plants to cure digestive disease[5]. This might be caused by the frequent visitation from the Department of Health and pharmacy students to Nagari Tuo Pariangan to promote the use of synthetic drugs. Synthetic drugs are much more practical compared to medicinal plants, making the people to prefer synthetic drugs to receive faster medication. Nagari Tuo Pariangan community is suspected to experience knowledge degradation on the medicinal plants from generation to generation.

The medicinal plants used by the Nagari Tuo Pariangan community to cure digestive diseases are also utilized as dish spice. Curcuma longais well-known as a spice which has the most benefits in dealing with digestive disease. This plant is commonly used by people from another Asian region as well, such as India, Bangladesh, and Pakistan[6]. Curcuma longa is able to increase the production of mucus at the gastric wall to overcome disorder on the stomach. Curcuma longa is also able to inhibit intestinal irritable bowel or gastritis disease that is caused by stress and alcohol. An experiment was conducted to 25 patients who suffered from peptic ulcer disease. These patients were administered with $600 \mathrm{mg}$ of $\mathrm{Y}$ powder 5 times a day. The result showed that $48 \%$ of the patients were fully cured from peptic ulcer disease[7]. Curcumin substance in $\mathrm{Y}$ is able to relieve diarrhea, neutrophil infiltration, and lipid peroxidation on colon tissue[8].

\section{CONCLUSION}

Nagari Tuo Pariangancommunity utilized 47 species of medicinal plants to cure digestive disease, belonging to 46 genus and 28 family. The people of 60-70 years old mostly use synthetic drug before using medicinal plants. The medicinal plants used were fewer compared to other places like in Bengkulu. This might be caused bythe tendency to use synthetic drugs and degradation of knowledge. Curcuma longais well-known as a spice which has the most benefits in dealing with digestive disease.

\section{REFERENCES}

[1] Hosseinzadeh S,Jafarikukhdan

A,HosseiniA\&Armand R 2015The

Application of Medicinal Plants in Traditional and Modern Medicine: A Review of Thymus vulgaris. International Journal of Clinical Medicine6:635-642.

[2] Hoang VS,Baas P\&Keßler PAJ 2008Tradisional medicinal plants in Ben En National Park, Vietnam. Blumea53:569-601.

[3] Dwivedi SN, Dwivedi S \& Patel PC 2006 Medicinal plants used by the tribal and rural people of Satna District, Madhya Pradesh for the treatment of gastrointestinal diseases and disorders. Natural Product Radiance 5(1):60-63.

[4] Olajuyigbe OO \& Afolayan AJ 2012 Ethnobotanical survey of medicinal plants used in the treatment of gastrointestinal disorders in the Eastern Cape Province, South Africa. Journal of Medicinal Plant Research6(18):34153424.

[5] Darwis W 2012 Tanaman obat yang terdapat di Kota Bengkulu yang berpotensi sebagai obat penyakit dan gangguan pada sistem pencernaan manusi. Konservasi Hayati 8(1):115 . 
[6] Chattopadhyay I, Biswas K, Bandyopadhyay U \& Banerjee RK 2004 Turmeric and curcumin: Biological actions and medicinal applications. Current Science India 87:44-53.

[7] Khajehdehi P 2012 Turmeric: Reemerging of a neglected Asian traditional remedy. Journal of Nephropathology 1(1):17-22.

[8] Perkins S, Verschoyle RD, Hill K, Parveen I, Threadgill MD, Sharma RA 2002 Chemopreventive efficacy and pharmacokinetics of curcumin in the $\mathrm{min} /+$ mouse, a model of familial adenomatous polyposis. Cancer Epidemiol Biomarkers Prevention 11:535-40. 